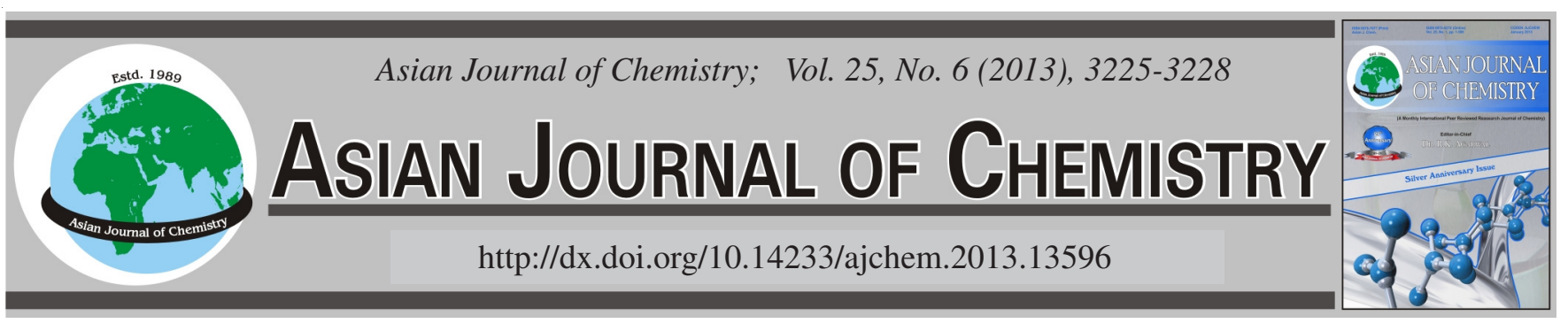

\title{
Synthesis, Characterization and Antimicrobial Activity of First Row Transition Metal(II) Complexes of Novel Schiff Base Derived from Sulfapyridine and Pyridine-2-Aldehyde
}

\author{
I. RAMA* and V. USHA
}

Post Graduate and Research Department of Chemistry, Seethalakshmi Ramaswami College, Tiruchirappalli-620 002, India

*Corresponding author: E-mail: rama14jai@yahoo.co.in

(Received: 15 February 2012;

Accepted: 14 December 2012)

AJC-12553

A new Schiff base ligand (N-pyridin-2-yl-4-[(pyridin-2-yl)methyl amino]benzene sulfonamide) (L) was prepared by the reaction between sulfapyridine and pyridine-2-aldehyde. The ligand is bidentate by coordinating through pyridinyl nitrogen and azomethine nitrogen atom with $\mathrm{Co}(\mathrm{II}), \mathrm{Ni}(\mathrm{II}), \mathrm{Cu}(\mathrm{II}), \mathrm{Zn}$ (II) and $\mathrm{Mn}$ (II) chlorides. The complexes were synthesized and characterized by elemental analysis, molar conductance, magnetic moment, IR, $\mathrm{H}^{1} \mathrm{NMR}$ and electronic spectral data. These complexes were screened in vitro antibacterial activity against the test microorganisms Staphylococcus aureus, Pseudomonas aeruginosa and fungi Candida albicans and Aspergillus niger. The results of these studies revealed that all complexes exhibit significant to moderate antimicrobial activity.

Key Words: Sulfapyridine, Transition metal complexes, Antibacterial, Schiff base.

\section{INTRODUCTION}

The application of inorganic chemistry to medicine is rapidly developing field and novel therapeutic and diagnostic metal complexes are now having an impact on medical practice. Advances in bio-coordination chemistry are vital for improving the design of compounds to reduce toxic sideeffects and understand their mechanisms of action. Most of the pharmaceutical agents contain metal compounds which are in current clinical use $\mathrm{e}^{1,2}$ and new areas of applications are rapidly emerging. The prominent biological activity of the metal complexes of Schiff bases derived from sulfa drugs has led to considerable interest in their coordination chemistry. The condensation products of sulfa drugs with aldehydes and ketones are biologically active and also form complex with metal ions ${ }^{3-5}$. Many chemotherapeutically important sulfa drugs like sulfadiazine, sulfapyridine, sulfamerazine possess $-\mathrm{SO}_{2} \mathrm{NH}$ - moiety which is an important toxophoric functional group. Schiff base derived from sulfanethioxazole and salicylaldehyde or thiophene-2-aldehyde and also the complexes derived from these Schiff bases show toxicity against insects ${ }^{6}$.

Among the metal complexes it is well known that transition metal complexes inhibit DNA and RNA polymerase activities and induce strand scission of DNA in presence of $\mathrm{H}_{2} \mathrm{O}_{2}{ }^{7}$. First row transition metal complexes of copper, zinc, cobalt etc., have attracted much attention due to their biological importance $^{8}$. Many heterocyclic aldehydes ${ }^{9}$ are known to be potential inhibitors for DNA synthesis. If heterocyclic aldehydes like indole-2-aldehyde and pyrrole-2-aldehyde are coupled with sulfa drugs the resulting compound sulfadrugimine can act as an effective antibacterial agent ${ }^{10}$. In the present investigation an attempt has been made to synthesize Schiff base by coupling pyridine-2-aldehyde and sulfapyridine and also its complexes with various first row transition metal chlorides.

\section{EXPERIMENTAL}

All the reagents and solvents used were of analar grade. All the metal(II) complexes were prepared by using corresponding metal chlorides. Microanalyses of carbon, hydrogen and nitrogen were carried out at SAIF, IIT, Madras, India. IR spectra were recorded as $\mathrm{KBr}$ pellets on a Shimadzu 8000 FTIR spectrophotometer in the range of $4000-400 \mathrm{~cm}^{-1} .{ }^{1} \mathrm{H}$ NMR spectra of compounds were recorded with a Bruker Spectrospin Avance DPX-400 using TMS as internal standard and DMSO- $d_{6}$ as solvent. UV-visible spectra were obtained in DMF on a Perkin Elmer Lambda 35 spectrophotometer in the range of 190-1100 nm. Magnetic susceptibility measurements were carried out on solid compounds at National Institute of Technology, Trichy, India. Conductance measurements were studied using Elico conductivity bridge and dip type conductivity cell. Melting points were determined by using Elico melting point apparatus. In vitro antibacterial and antifungal screening were studied at Periyar Maniammai Pharmaceutical College, Trichy, India.

Synthesis of Schiff-base ligand (L): A hot ethanolic solution of pyridine-2-aldehyde $(0.0125 \mathrm{~mol})$ was added to a 
hot ethanolic solution of sulfapyridine $(0.0125 \mathrm{~mol})$. The mixture solution was then refluxed on a water bath for 4-5 $\mathrm{h}$. A coloured solid mass separated out on cooling which was filtered, washed several times and subsequently dried over anhydrous $\mathrm{CaCl}_{2}$ in a desiccator and recrystallised from ethanol (m.p. $134^{\circ} \mathrm{C}$, yield $78 \%$ ).

Synthesis of metal(II) complexes: To a hot magnetically stirred dioxane solution of Schiff base ligand (0.003 mol), an aqueous solution of the corresponding metal(II) chloride $(0.0015 \mathrm{~mol})$ was added. The mixture was refluxed for $6 \mathrm{~h}$ in a heating mantle. The bright coloured complex separated out on cooling, was filtered by suction, washed and dried in vacuo over anhydrous $\mathrm{CaCl}_{2}$. The yields of the complexes were $50-80 \%$.

Antimicrobial activity: The synthesized ligand and the metal complexes were screened in vitro for antimicrobial activity against pathogenic bacterial species (Staphylococcus aureus and $P$. aeruginosa) and fungi (Candida albicans and A. niger) by diffusion plate method ${ }^{11}$. The results were recorded and compared with standard drug.

\section{RESULTS AND DISCUSSION}

The Schiff base ligand was synthesized by refluxing an equimolar ratio of sulfapyridine and pyrindine-2-aldehyde in hot ethanolic medium. The composition of the ligand is consistent with its micro analytical data. The structure of the synthesized ligand was established with the help of IR, NMR and micro analytical data. The complexes are microcrystalline coloured powders having melting points higher than the ligand. They are stable in air and non-hygroscopic in nature. All complexes gave satisfactory elemental analysis suggesting 1:2
(M:L) stoichiometry. The physical characteristics, micro analytical data, conductance and magnetic moment values of the metal complexes and the ligand are given in the Table-1.

Conductance and magnetic susceptibility measurements: The molar conductance values fell within the range of 6.18-39.32 $\mathrm{ohm}^{-1} \mathrm{~cm}^{2} \mathrm{~mol}^{-1}$ for all complexes showing the non-electrolytic ${ }^{12}$ nature. This suggested that the chloride ions are coordinated with the metal ions. The observed magnetic moment value for $\mathrm{Co}$ (II) and $\mathrm{Ni}$ (II) complex (4.64 and 3.24 BM) suggest octahedral geometry for these complexes ${ }^{13}$. The observed magnetic moment value for copper(II) complex (1.77 $\mathrm{BM})$ lie in the range as expected for a $d^{9}$ system, which contains one unpaired electron with octahedral geometry ${ }^{14}$. The zinc(II) complex was found to be diamagnetic ${ }^{15}$ as expected. The manganese(II) complex has a magnetic moment value of 5.85 $\mathrm{BM}$ indicating high spin octahedral environment ${ }^{16}$ around manganese.

Infrared spectra: The important IR spectral bands of the ligand and its metal complexes are given in the Table- 2 . Potential electron pair donor sites of the synthesized ligand are the pyridinyl nitrogen, the azomethine nitrogen, the sulfonamide oxygens and the sulfonamide nitrogen. In the IR spectra of the ligand a sharp band observed in the region 1632 $\mathrm{cm}^{-1}$ and a medium sharp band at $1387 \mathrm{~cm}^{-1}$ were assigned ${ }^{17}$ to the $v(-\mathrm{HC}=\mathrm{N}-)$ mode of azomethine and $v(\mathrm{C}-\mathrm{N})$ stretching of pyridinyl ring, respectively. Evidence of the nitrogen bonding of azomethine $(-\mathrm{HC}=\mathrm{N}-)$ group to the central metal atom stems from the shift of the $v(-\mathrm{HC}=\mathrm{N}-)$ band to lower frequency by $21-42 \mathrm{~cm}^{-1}$ in all the complexes. The coordination through the pyridinyl ring nitrogen was revealed by shifting of the $v(C-N)$

\begin{tabular}{|c|c|c|c|c|c|c|c|c|c|}
\hline \multirow{3}{*}{ Compound } & \multirow{3}{*}{$\begin{array}{r}\text { PHYSICAL } \\
\text { DATA OF SCl } \\
\text { Colour }\end{array}$} & \multirow{3}{*}{$\begin{array}{l}\text { m.p. } \\
\left({ }^{\circ} \mathrm{C}\right)\end{array}$} & \multirow{3}{*}{$\begin{array}{r}\text { TA } \\
\text { TERIS } \\
\text { E LIGA } \\
\begin{array}{c}\text { Yield } \\
(\%)\end{array}\end{array}$} & \multicolumn{5}{|c|}{$\begin{array}{l}\text { BLE-1 } \\
\text { ICS AND MICRO ANALYTICAL } \\
\text { ND AND ITS METAL COMPLEXES }\end{array}$} & \multirow{3}{*}{$\begin{array}{c}\Lambda_{\mathrm{m}} \\
\left(\mathrm{ohm}^{-1} \mathrm{~cm}^{2}\right. \\
\left.\mathrm{mol}^{-1}\right)\end{array}$} \\
\hline & & & & \multicolumn{3}{|c|}{$\begin{array}{c}\text { Elemental analysis (\%) calcd. } \\
\text { (observed) }\end{array}$} & \multirow[t]{2}{*}{ Geometry } & \multirow{2}{*}{$\mu_{\mathrm{Eff}}$} & \\
\hline & & & & $\mathrm{C}$ & $\mathrm{H}$ & $\mathrm{N}$ & & & \\
\hline $\begin{array}{l}{\left[\mathrm{C}_{17} \mathrm{H}_{14} \mathrm{~N}_{4} \mathrm{SO}_{2}\right]} \\
(\mathbf{L})\end{array}$ & Yellow & 134 & 78 & $\begin{array}{c}60.30 \\
(60.21)\end{array}$ & $\begin{array}{c}4.20 \\
(3.81)\end{array}$ & $\begin{array}{c}16.60 \\
(16.31)\end{array}$ & - & - & - \\
\hline $\begin{array}{l}{\left[\mathrm{Co}\left(\mathrm{C}_{17} \mathrm{H}_{14} \mathrm{~N}_{4} \mathrm{SO}_{2}\right)_{2} \mathrm{Cl}_{2}\right] /\left[\mathrm{Co}(\mathrm{L})_{2} \mathrm{Cl}_{2}\right]} \\
(\mathbf{L A})\end{array}$ & Orange & 240 & 54 & $\begin{array}{c}50.60 \\
(50.33)\end{array}$ & $\begin{array}{c}3.50 \\
(3.42)\end{array}$ & $\begin{array}{c}13.90 \\
(13.43)\end{array}$ & Octahedral & 4.64 & 31.85 \\
\hline $\begin{array}{l}{\left[\mathrm{Ni}\left(\mathrm{C}_{17} \mathrm{H}_{14} \mathrm{~N}_{4} \mathrm{SO}_{2}\right)_{2}\right] \mathrm{Cl}_{2} /\left[\mathrm{Ni}(\mathrm{L})_{2} \mathrm{Cl}_{2}\right]} \\
(\mathrm{LB})\end{array}$ & $\begin{array}{l}\text { Greenish } \\
\text { yellow }\end{array}$ & 250 & 52 & $\begin{array}{c}50.63 \\
(50.55)\end{array}$ & $\begin{array}{c}3.50 \\
(3.25)\end{array}$ & $\begin{array}{c}13.90 \\
(13.17)\end{array}$ & Octahedral & 3.24 & 30.96 \\
\hline $\begin{array}{l}{\left[\mathrm{Cu}\left(\mathrm{C}_{17} \mathrm{H}_{14} \mathrm{~N}_{4} \mathrm{SO}_{2}\right)_{2} \mathrm{Cl}_{2}\right] /\left[\mathrm{Cu}(\mathrm{L})_{2} \mathrm{Cl}_{2}\right]} \\
(\mathbf{L C})\end{array}$ & $\begin{array}{l}\text { Dark } \\
\text { green }\end{array}$ & 195 & 59 & $\begin{array}{c}50.30 \\
(50.04)\end{array}$ & $\begin{array}{c}3.50 \\
(3.43)\end{array}$ & $\begin{array}{c}13.80 \\
(13.45)\end{array}$ & Octahedral & 1.77 & 39.32 \\
\hline $\begin{array}{l}{\left[\mathrm{Zn}\left(\mathrm{C}_{17} \mathrm{H}_{14} \mathrm{~N}_{4} \mathrm{SO}_{2}\right)_{2} \mathrm{Cl}_{2}\right] /\left[\mathrm{Zn}(\mathrm{L})_{2} \mathrm{Cl}_{2}\right]} \\
(\text { LD) }\end{array}$ & $\begin{array}{c}\text { Dark } \\
\text { brown }\end{array}$ & 157 & 63 & $\begin{array}{c}50.20 \\
(50.03)\end{array}$ & $\begin{array}{c}3.50 \\
(3.06)\end{array}$ & $\begin{array}{c}13.80 \\
(12.96)\end{array}$ & Octahedral & Dia & 11.6 \\
\hline $\begin{array}{l}{\left[\mathrm{Mn}\left(\mathrm{C}_{17} \mathrm{H}_{14} \mathrm{~N}_{4} \mathrm{SO}_{2}\right)_{2} \mathrm{Cl}_{2}\right] /\left[\mathrm{Mn}(\mathrm{L})_{2} \mathrm{Cl}_{2}\right]} \\
(\mathbf{L E})\end{array}$ & Grey & 170 & 81 & $\begin{array}{r}50.90 \\
(50.61) \\
\end{array}$ & $\begin{array}{r}3.50 \\
(3.21) \\
\end{array}$ & $\begin{array}{c}13.97 \\
(13.88) \\
\end{array}$ & Octahedral & 5.85 & 6.78 \\
\hline
\end{tabular}

TABLE-2

IMPORTANT ELECTRONIC AND IR SPECTRAL BANDS IN SCHIFF BASE LIGAND AND ITS METAL COMPLEXES

\begin{tabular}{|c|c|c|c|c|c|c|c|c|}
\hline \multirow[b]{2}{*}{ Comp. } & \multirow{2}{*}{\multicolumn{2}{|c|}{ Electronic spectral bands $\left(\lambda_{\max }\right)\left(\mathrm{cm}^{-1}\right)$}} & \multicolumn{6}{|c|}{ IR Spectral bands $\left(\mathrm{cm}^{-1}\right)$} \\
\hline & & & $v(\mathrm{~N}-\mathrm{H})$ & $\begin{array}{l}v(-\mathrm{CH}=\mathrm{N}-) \\
\text { Azomethine }\end{array}$ & $\begin{array}{c}v(\mathrm{C}-\mathrm{N}) \text { Pyridynyl } \\
\text { nitrogen }\end{array}$ & $\begin{array}{l}\mathrm{v}_{\mathrm{a}}\left(\mathrm{SO}_{2}\right), \\
\mathrm{v}_{\mathrm{s}}\left(\mathrm{SO}_{2}\right)\end{array}$ & $v(\mathrm{~S}-\mathrm{N})$ & $v(\mathrm{M}-\mathrm{N})$ \\
\hline $\mathbf{L}$ & 28333,32424 & $\mathrm{M} \rightarrow \mathrm{L}$ & 3413 & 1632 & 1387 & 1276,1138 & 957 & - \\
\hline LA & 36498,37320 & $\mathrm{M} \rightarrow \mathrm{L}$ & 3415 & 1597 & 1358 & 1275,1134 & 957 & 492 \\
\hline LB & 32884 & $\mathrm{M} \rightarrow \mathrm{L}$ & 3418 & 1611 & 1373 & 1272,1130 & 961 & 483 \\
\hline LC & 36000 & $\mathrm{M} \rightarrow \mathrm{L}$ & 3413 & 1598 & 1363 & 1279,1134 & 960 & 494 \\
\hline LD & $32232,33919,35039,35869$ & $\mathrm{M} \rightarrow \mathrm{L}$ & 3407 & 1609 & 1366 & 1273,1139 & 953 & 460 \\
\hline $\mathbf{L E}$ & 29412 & ${ }^{6} \mathrm{~A}_{1 \mathrm{~g}} \rightarrow{ }^{4} \mathrm{E}_{\mathrm{g}}(\mathrm{D})$ & 3413 & 1590 & 1368 & 1260,1134 & 946 & 490 \\
\hline
\end{tabular}


band to lower frequencies by $14-29 \mathrm{~cm}^{-1}$ in all the complexes as compared with that of the ligand. This is further confirmed by the appearance of the new bands at $490-460 \mathrm{~cm}^{-1}$ due to the $v(\mathrm{M}-\mathrm{N})$ bands $^{18}$ in metal complexes. The bands in the ligand due to $v_{\mathrm{a}}\left(\mathrm{SO}_{2}\right)$ and $\mathrm{v}_{\mathrm{s}}\left(\mathrm{SO}_{2}\right)$ appeared at 1275-1235 and 1140$1125 \mathrm{~cm}^{-1}$, respectively ${ }^{19}$. These bands remain almost unchanged in the complexes indicating that this group does not participate in coordination. This is supported by the unchanged $v(\mathrm{~S}-\mathrm{N})$ mode $\mathrm{e}^{20}$ appearing at $965-945 \mathrm{~cm}^{-1}$ in the ligand even after complexation.

${ }^{1} \mathbf{H}$ NMR spectra: ${ }^{1} \mathrm{H}$ NMR spectra of the free ligand and its complexes were recorded in DMSO- $d_{6}$. The proton $\mathrm{nmr}$ signal observed at $\delta=8.5 \mathrm{ppm}$ in the spectra of the ligand is due to azomethine $(-\mathrm{HC}=\mathrm{N}-)$ proton. The azomethine proton shifts upfield upon complexation due to the increased conjugation and coordination. This also confirms the coordination by azomethine nitrogen ${ }^{21}$, which has already been shown by IR spectral data.

Electronic spectra: The electronic spectra of the complexes were taken in DMF solution and presented in the Table2. The Co(II) complex exhibited well-resolved, two high energy bands at 36,498 and $37,320 \mathrm{~cm}^{-1}$ which are assigned ${ }^{22}$ to the metal to ligand charge transfer. The $\mathrm{Ni}(\mathrm{II})$ and $\mathrm{Cu}(\mathrm{II}))$ complexes also exhibited strong high energy bands at 32,884 and $36,000 \mathrm{~cm}^{-1}$ in turn, assigned to metal to ligand charge transfer. The electronic spectra of the $\mathrm{Zn}$ (II) complex exhibited four high-intensity bands at 32232, 33919, 35039 and 35869 $\mathrm{cm}^{-1}$ and are assigned to metal to ligand charge transfer. The electronic spectra of $\mathrm{Mn}$ (II) complex show only one band at $29,412 \mathrm{~cm}^{-1}$ assigned ${ }^{23}$ to the transition ${ }^{6} \mathrm{~A}_{\mathrm{lg}} \rightarrow{ }^{4} \mathrm{E}_{\mathrm{g}}(\mathrm{D})$ consistent with octahedral configuration.

Antimicrobial activity: Disc diffusion technique has been used for determining the activity of Schiff base ligand and complexes against bacterial species and fungi. It is clear from the biological data that the ligand and complexes has significant antimicrobial activities against the pathogenic bacteria. The results compared with standard drug (ciprofloxacin $5 \mu \mathrm{g} /$ disc for bacteria; Nystatin 100 units/ disc for fungi) have indicated that compounds were active but activity was lesser than the standard drugs. The results thus obtained are explained on the basis of Overtone's concept and chelation theory ${ }^{24}$. Comparisons of the biological activity of the synthesized compounds and standard are presented in Table- 3 shows the free Schiff base ligand and some of its complexes exhibit better activity. The activity decreases in the case of manganese complexes when compared to ligand. In specific the Nickel and copper complexes of the ligand show very high activity against the bacteria Staphylococcus aureus, which indicates the remarkable antibacterial activity when compared to the rest of the complexes which is shown in the Fig. 1. In overall the activity of the ligand is enhanced after chelation with metal and thus the biological activity increases on complexation.

\section{Conclusion}

In this paper the preparation and characterization of a new Schiff base derived from 2-pyridine carbaldehyde and sulfapyridine has been reported. From the satisfactory micro analytical and various spectral data, it is concluded that ligand acts as

\begin{tabular}{lcccc} 
& \multicolumn{4}{c}{ TABLE-3 } \\
& \multicolumn{3}{c}{ ANTIMICROBIAL ACTIVITY OF } \\
THE LIGAND AND COMPLEXES
\end{tabular}

Standard: Ciprofloxacin $5 \mu \mathrm{g} /$ disc for bacteria; Nystatin 100 units/disc for fungi.

\section{Antibacterial activity}

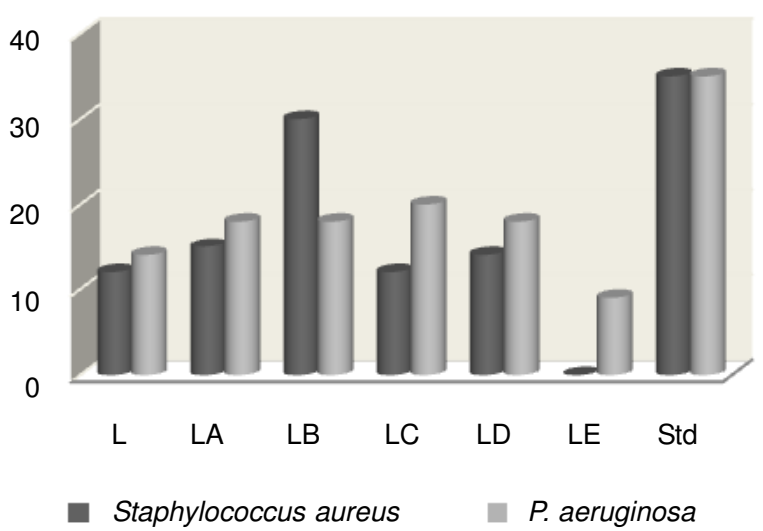

Antifungal activity

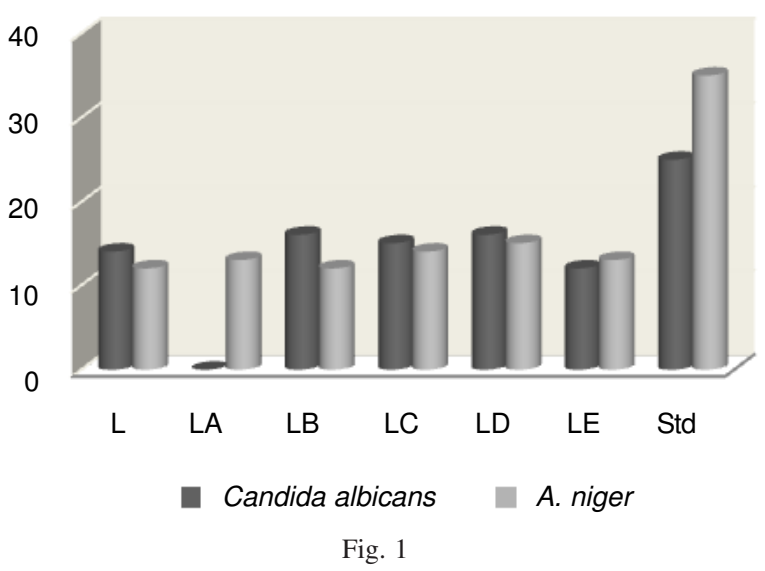

neutral bidentate ligand and its structrure is shown in the Fig. 2. The metal chelates of ligand have been structurally characterised. The metal ligand stoichiometry in all these complexes is 1:2. It is tentatively proposed that the Schiff base ligand coordinates through the nitrogen of the azomethine group and the nitrogen of the pyridinyl ring, forming a stable chelate ring structure. On the basis of the above discussions, it is concluded that all the complexes exhibit six-coordinated octahedral geometry as shown in the Fig. 3. Biological studies of the complexes reveal that these complexes show better activity compared to that of the ligand. 


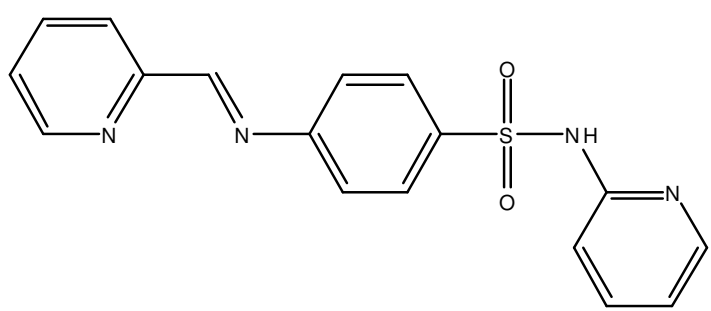

$N$-(Pyridine-2-yl)-4-(pyridine-2-yl methylene amino)benzene sulfornamide Fig. 2. Structure of schiff base ligand (L)

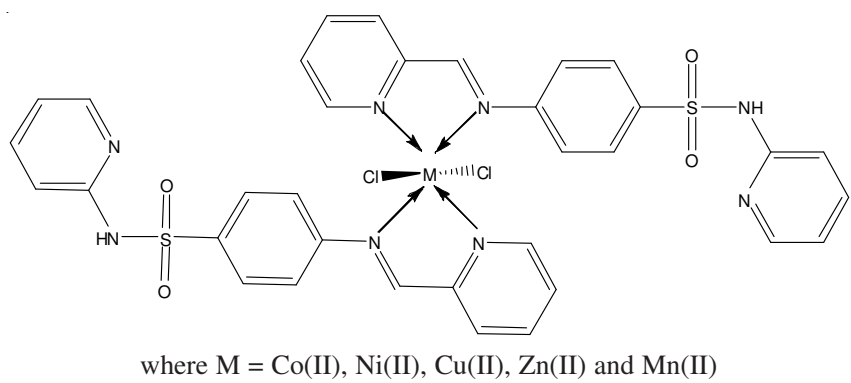

Fig. 3. Structure of the complexes of Schiff base with octahedral geometry

\section{ACKNOWLEDGEMENTS}

The authors are grateful to The Secretary, Seethalakshmi Ramaswami College for providing laboratory facilities and Dr. Karvembu, National Institute of Technology, Trichy for helping us in taking magnetic susceptibility data. The authors aslo expressed their gratitude to Assoc. Prof. Dr. R. Selvameena, Dr.R. Subbalakshmi and faculty members of the Department of Chemistry, Seethalakshmi Ramaswami College, Trichy for help.

\section{REFERENCES}

1. P.J. Sadler, Adv. Inorg. Chem., 36, 1 (1991).

2. M.J. Abrams and B.A. Murrer, Science, 261, 725 (1993).

3. G.D. Tiwari and M.N. Mishra, Curr. Sci. 49, 8 (1980).

4. K. Lal and R.K. Shukla, J. Indian Chem. Soc., 58, 115 (1981).

5. A.K. Varshney and J.P. Tandon, Polyhedron, 5, 1853 (1986).

6. K.S. Siddique, R.I. Kureshy, S. Tabassum and S. Zaidi, Inorg. Chem. Acta, 151, 95; Chem. Abstr., 108 (1988).

7. N. Raman, S.J. Raja, J. Joseph, A. Sakthivel and J.D. Raja, J. Chil. Chem. Soc., 53, 1599 (2008).

8. K. Singh, M.S. Barwa and P. Tyagi, Eur. J. Med. Chem., 41, 147 (2006).

9. W. Wang, H. Li, J. Wang and L.S. Zu, J. Am. Chem. Soc., 128, 10354 (2006).

10. H.L. Singh, M. Sharma and A.K. Varshney, ACGC Chem. Res. Commun., 8, 35 (1998); Chem. Abstr., 131, 110367 (1999).

11. Indian Pharmacopoeia, IIA, 105 (1996).

12. W.I. Geary, Coord. Chem. Rev., 7, 81 (1971).

13. F.A. Cotton and G. Wilkinson, Advanced Inorganic Chemistry, John Wiley \& Sons, New York, edn. 5, p. 631 (1988).

14. B.C. Khade, W.N. Jadhav, R.P. Pawar, A.U. Deshmukh, S.R. Kundikar, V.J. Kulkarni and M.V. Lokhande, Asian J. Chem., 16, 947 (2004).

15. R.C. Maurya, D.D. Mishra and S. Mukherjee, Synth. React. Inorg. Met. Org. Chem., 21, 1107 (1991).

16. S. Chandra, M. Tyagi and K. Sharma, J. Iran. Chem. Soc., 6, 310 (2009).

17. I.J. Bellamy, The Infra Red Spectra of Complex Molecules, New York; John Wiley (1971).

18. J.R. Ferrero, Low-Frequency Vibrations of Inorganic and Coordination Compounds, Wiley, New York (1971).

19. G.R. Burns, Inorg. Chem., 7, 277 (1968).

20. R.C. Maurya and P. Patel, Spectr. Lett., 32, 213 (1999).

21. D.J. Pasto, Organic Structure Determination, London, UK, Prentice Hall (1969).

22. Z.H. Chohan and M.M. Naseer, App. Organomet. Chem., 21, 728 (2007).

23. J.D. Lee, Concise Inorganic chemistry, Blackwell Science, Reprint, edn. 5, p. 967 (1999)

24. R.S. Srivastava, Inorg. Chim. Acta, 56, 65 (1944). 